\title{
Palaeoecology and Archaeology of the Kärlich-Seeufer Open-Air Site (Middle Pleistocene) in the Central Rhineland, Germany
}

\author{
SABINE GAUdZINSKI \\ Forschungsbereich Altsteinzeit des Römisch-Germanischen-Zentralmuseums Mainz, Schloss Monrepos, 56567 Neuwied, Germany \\ Felix BitTMANN \\ Institut für Palynologie und Quartärwissenschaften, Universität Göttingen, Wilhelm-Weber-Strasse 2, 37073 Göttingen, Germany \\ WolfGang BoENigK AND MANFRED FReCHEN \\ Geologisches Institut der Universität zu Köln, Zülpicher Strasse 49a, 50674 Köln, Germany
}

AND

THISS VAN KOLFSCHOTEN

Faculteit der Pre- en Protohistorie, Rijksuniversiteit Leiden, Postbus 9515, 2300 RA Leiden, The Netherlands

Received July 6, 1995

The Kärlich-Seeufer archaeological site in Germany's central Rhineland was excavated between 1980 and 1992 . The site provides evidence for hominid activity during a Middle Pleistocene interglaciation known up to now only from the Kärlich clay pit and therefore defined as the Kärlich Interglaciation, which is considered to be post-Cromer IV and pre-Holstein (sensu stricto) in age. The site is characterized by Acheulean artifacts, a fauna dominated by Elephas (Palaeoloxodon) antiquus, and a unique and outstanding preservation of wooden and other palaeobotanical remains. Assuming all finds are associated, the site previously was interpreted as an elephant hunting camp with a wooden structure, together with wood and bone implements preserved in situ. Recent analysis of the same features has shown that the site can also be interpreted as a reworked archaeological sample. Hominid occupation occurred in the vicinity of a small lake with prevailing mesooligotrophic conditions. Expanding boreal forests and fen vegetation characterized the landscape. 1996 University of Washington.

\section{INTRODUCTION}

The discovery of lithics and bones in Middle Pleistocene interglacial sediments, with outstanding preservation of paleobotanical remains, led to the excavation of the KärlichSeeufer site. The study was undertaken in order to obtain data about the chronostratigraphy of Middle Pleistocene interglaciations and detailed information about paleoenvironmental conditions during hominid occupation. Knowledge about utilization of wood for tool production had been expected.

\section{TOPOGRAPHIC SETTING}

The Middle Pleistocene open-air Kärlich-Seeufer site is located $7 \mathrm{~km}$ northwest of Koblenz in the Neuwied Basin of Germany (Fig. 1). The Neuwied Basin is part of a tectonic depression in the center of the Rheinisches Schiefergebirge. It is part of the West European Rift System that extends from the Rhône Valley through the Rhine Valley and the Netherlands to the North Sea (Fig. 1). The open-air site is situated in the Kärlich clay pit, at an altitude of $170 \mathrm{~m}$.

\section{GEOLOGY}

The Kärlich clay pit has been the most important exposure for the Quaternary stratigraphy of the central Rhineland since the beginning of this century. More than $30 \mathrm{~m}$ of exposed Pleistocene sediments have been investigated for more than $80 \mathrm{yr}$.

The Pleistocene sequence (Fig. 2) begins with a gravel layer belonging to the main terrace (Hauptterrasse) of the river Rhine (Razi Rad, 1976). The lower part of the Hauptterrasse sediments were deposited by the Rhine (Fig. 2, Ba) and have reversed magnetic polarity, whereas the upper part was deposited by the Moselle River (Fig. 2, Bb). Normal magnetic polarity has been detected within these deposits as well as in all overlying beds. Therefore, the Brunhes/ Matuyama boundary is located at the Rhine/Moselle gravel transition (Boenigk et al., 1974). The coverbeds consist of ca. $28 \mathrm{~m}$ of loess and loess derivatives with intercalated interglacial soils and tephra layers (Brunnacker et al., 1969; Schirmer, 1990).

Volcanic activity in the central Rhineland is first documented 


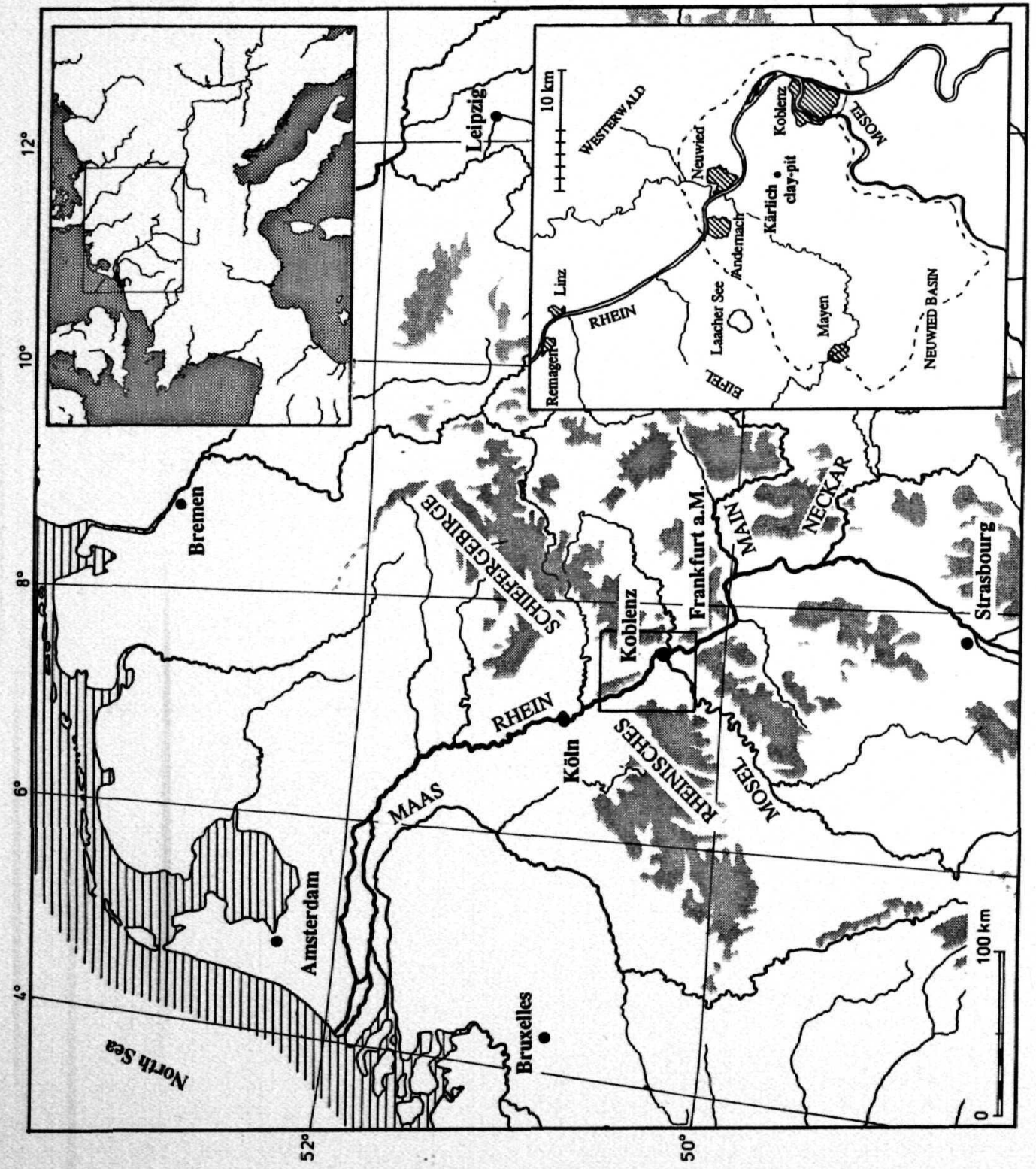

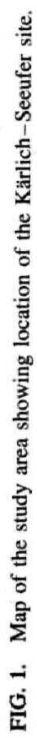




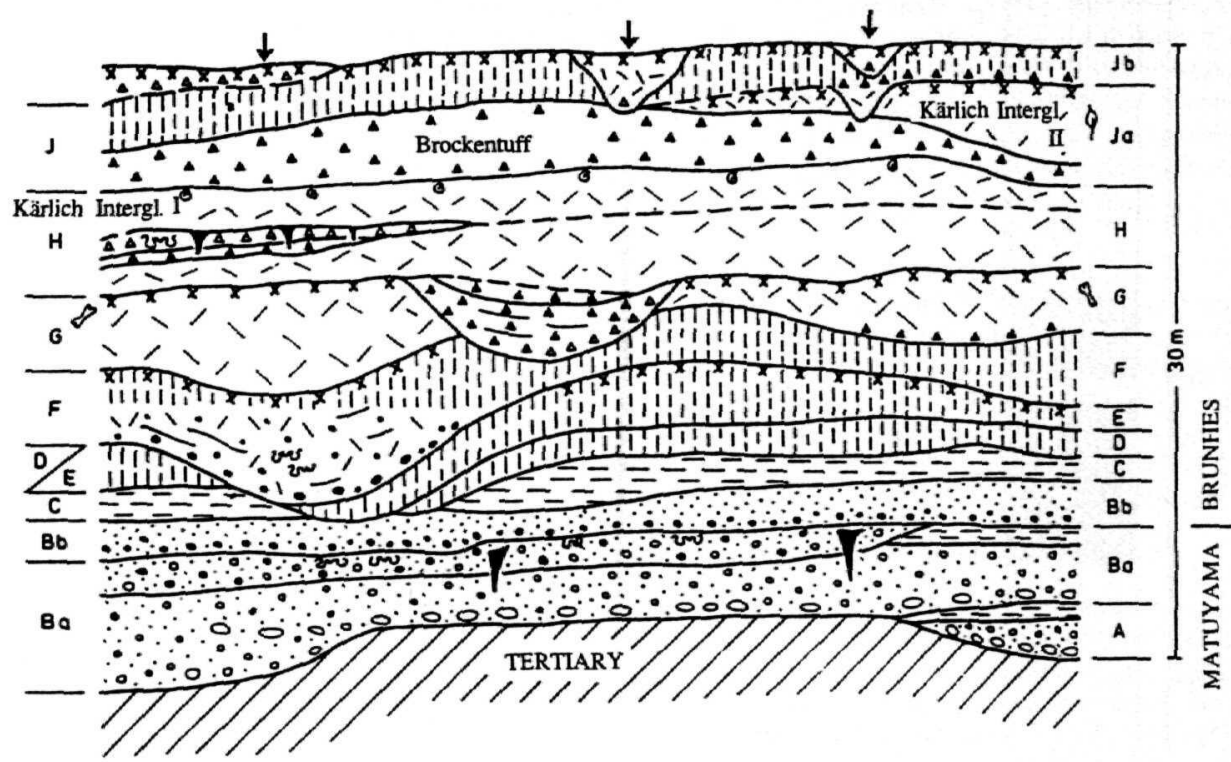

\begin{tabular}{|c|c|c|c|c|c|c|}
\hline 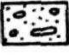 & Rhein gravel & Mosel and local gravel & {$[\because \because 3$} & Sand & -2 & Flood loam \\
\hline & Loess & Loess like material & $\therefore \Delta$ & Pumice & 4.4 & Basalt tephra \\
\hline
\end{tabular}

FIG. 2. Schematic stratigraphy of the sedimentary sequence in the clay pit Kärlich.

in Unit G (Fig. 2) of the Kärlich sequence by volcanic minerals and basaltic tephra layers. Unit $G$ also contains an interglacial micromammal fauna characterized by the first occurrence of Anvicola terrestris cantiana (v. Kolfschoten and Turner, 1996). Biostratigraphically, the microfauna can be related to the lower part of the Arvicola terrestris cantiana range zone, which is correlated with the Cromer IV Interglaciation of the Dutch Pleistocene stratigraphy (v. Kolfschoten, 1990).

The loessic sediments of the overlying unit $\mathrm{H}$ (Fig. 2) contain two intercalated layers of pumiceous tephra (Fig. 2, Kae-DT1 and Kae-DT2). Dating of the sediment sequence and the tephra layers by the ${ }^{40} \mathrm{Ar} /{ }^{39} \mathrm{Ar}$ stepheating method (for Kae-DT1; Lippolt et al., 1986) and by ${ }^{40} \mathrm{Ar} /{ }^{39} \mathrm{Ar}$ single crystal laser grain method (for Kae-DT2; v. d. Bogaard and Schmincke, 1990) is still inconclusive, but it seems most likely that the two tephra layers in unit $\mathrm{H}$ have an age of about $450,000 \mathrm{yr}$. Unit $\mathrm{H}$ is topped by a reworked soil with an interglacial molluscan fauna (Brunnacker et al., 1969) representing the first part of the Kärlich Interglaciation. The following layer is the Kärlicher Brockentuff (Fig. 2), a tephra horizon up to $6 \mathrm{~m}$ thick formed by several monogenetic phreatomagmatic eruptions that formed maar-like craters (Frechen, 1995).

On top of the Brockentuff, lacustrine sediments accumulated in a former depression now exposed only within the southeast corner of the Kärlich clay pit. Although the exact origin of the depression has been debated (Bosinski et al., 1980; v. d. Bogaard et al., 1989), a volcano-tectonic origin seems most likely in view of the presence of phreatomagmatic eruption centers of one or several maars east of the southeast corner of the clay pit. This interpretation is also supported by the presence of lake sediments within the depression that indicate a plateau position (Boenigk and Frechen, in press a).

Immediately after the formation of the depression, minor earth slides occurred that moved Moselle River gravel, loess, 


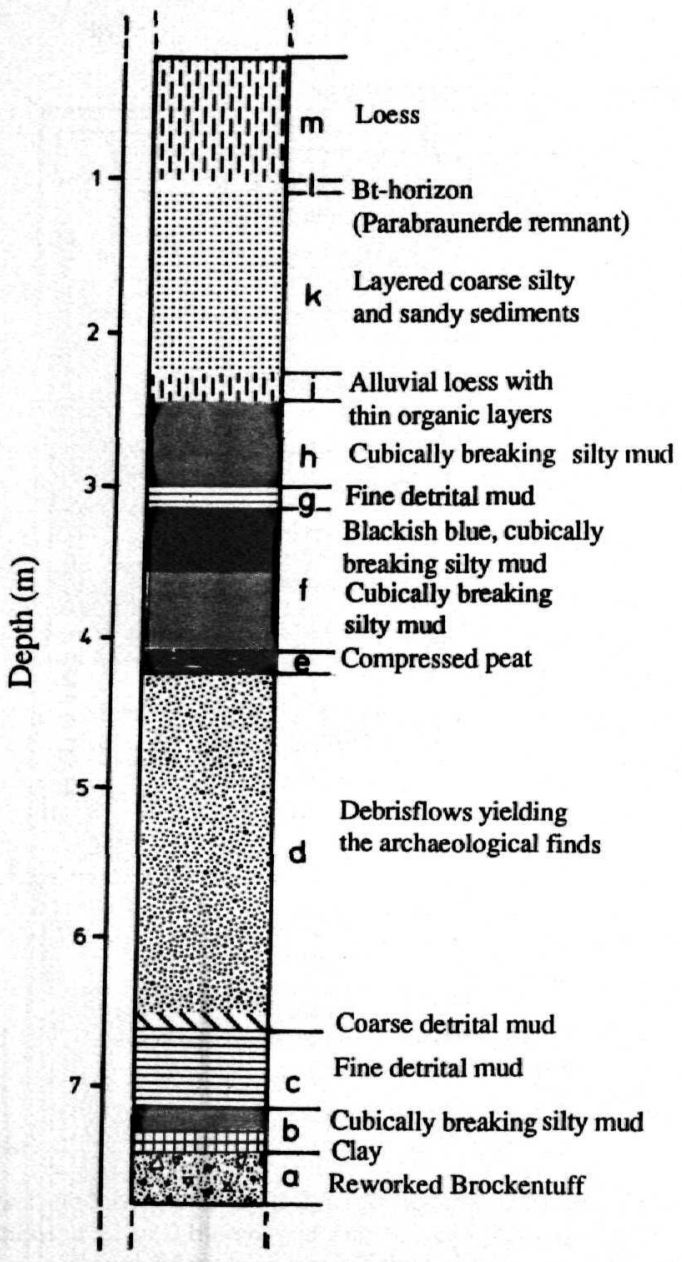

FIG. 3. Schematic simplified geologic section of Kärlich-Seeufer.

and loess derivatives of the older part of the Pleistocene Kärlich sequence into the depression. Subsequently, slope debris, mainly reworked Brockentuff, was deposited (Fig. 3, unit a). Next, clay (Fig. 3, unit b) accumulated and a lake formed. The sediments of this lake become finer toward the top of the sequence, with an increase in the organic content of the sediment. In a period of stability, resulting in a very low sedimentation rate, the depression was filled with detrital muds (Fig. 3, unit c) which are finer toward the center and coarser toward the edge of the lake. The overlying sediments yield the archaeological finds and consist of several layers of sandy debris flows, which are up to $2.4 \mathrm{~m}$ thick (Fig. 3, unit d) at the edge of the depression. Finer-grained mudflow units are stratigraphically equivalent sediments toward the center of the depression. They represent a short period of time when the land surface was unstable and point to the destruction of the forest vegetation at the end of the Kärlich Interglaciation.

Lacustrine sediments, as well as the artifact-yielding deposits, represent the second part of the Kärlich Interglaciation. Only the first part of the interglaciation, documented by the mollusc fauna below the Brockentuff, was originally defined as the Kärlich Interglaciation (Brunnacker et al., 1969). The same term was also used for warm-climate deposits above the Brockentuff discovered $10 \mathrm{yr}$ later, assuming that these sediments belong to the same warm phase (Urban, 1978; Bittmann, 1992). This is indicated by macroscopic remains of Acer campestre and Cornus mas found at the base of the Brockentuff (Schirmer, 1990), showing that the Brockentuff erupted during an interglaciation.

From a geologic point of view, it cannot be excluded that the soil yielding the molluscs, now representing the Kärlich Interglaciation I, was reworked by periglacial processes. Therefore, the possibility of two interglaciations has to be considered. For this reason a subdivision of the Kärlich Interglaciation (Kärlich Interglaciation I below the Brockentuff, Kärlich Interglaciation II above the Brockentuff) has been suggested (Boenigk and Frechen, in press b).

Above the sediments representing the Kärlich Interglaciation, II mudflow layers, waterlain clay and silt and three horizons rich in organic matter were deposited in a sequence up to $2 \mathrm{~m}$ thick (Fig. 3, units e-i). These document a swampy environment with some open patches of water. Above the uppermost layer of organic material (Fig. 3, unit i) within this sequence a significant change in sedimentation took place. The absence of a permanent lake or swamp is indicated by a sequence of well-layered sediments rich in clay and up to $10 \mathrm{~m}$ thick (Fig. 3, unit k), showing a change in color from dark gray and black to brown. Sedimentation was controlled by slope wash and the sediments alternate from fine to coarse silty sand. Two light-gray soils (pseudogleys) are intercalated in this sequence, documenting an interruption in sedimentation. The top of the sequence is characterized by a clay-rich brown soil, a remnant of the Bt horizon (Fig. 3, unit 1 ) of a well-developed forest soil (Parabraunerde). At the Seeufer site, the uppermost sediments consist of unweathered yellowish loess (Fig. 3, unit m), rich in carbonate.

\section{GEOCHRONOLOGICAL POSITION}

Palaeontological investigations of small mammals from the upper part of Unit $\mathbf{G}$ of the Kärlich clay pit characterize the microfaunal assemblage as belonging to the Arvicola terrestris cantiana-Sorex-(Drepanosorex sp.) Concurrent-range-subzone, which is assigned to Interglaciation

his

\section{de}


IV of the Cromer complex and to the beginning of the Elster Glaciation (v. Kolfschoten, 1990).

Deposits of the Kärlich Interglaciation I and II are separated from Unit $G$ by a horizon with ice wedges (Fig. 2), suggesting an age younger than that of Cromer IV, known hitherto as the youngest interglaciation of the Cromer Complex in the Dutch Pleistocene stratigraphy (Zagwijn, 1985).

Attempts to date the Brockentuff tephra, which separates deposits of the Kärlich Interglaciation I and II, gave a maximum age of $396,000 \pm 20,000 \mathrm{yr}\left({ }^{40} \mathrm{Ar} /{ }^{39} \mathrm{Ar}\right.$ single crystal laser method) (v. d. Bogaard et al., 1989), which is correlated with oxygen isotope stage (OIS) 11 (v. d. Bogaard et al., 1989). The whole Seeufer sequence is younger than the eruption of the Brockentuff and the formation of the depression formed during or after the eruption of the Brockentuff in which the archaeological site is situated.

The sedimentological-pedological results prove that the Kärlich Interglaciation II must be at least as old as OIS 7. Above the lacustrine sediments yielding the archaeological finds, cold-climate sediments have been deposited. The top of these sediments has been altered to an interglacial soil, a well-developed $\mathrm{Bt}$ horizon of a parabraunerde, a relict of an interglacial soil formation and assumed to be of Eemian Interglacial age. The section is topped by sediments interpreted as Weichselian loess.

As will be shown below, palynological investigation at the Kärlich-Seeufer site indicates that the Kärlich Interglaciation cannot be correlated with the Holstein Interglaciation. At present, an age younger than the Holstein Interglaciation can also not be corroborated due to the absence of reliably dated palynological and comparable sequences known in that position.

In conclusion, results of biostratigraphic, geologic, and palynologic analyses, together with results of physical dating methods, indicate that the Kärlich-Seeufer site is younger than $396,000 \pm 20,000 \mathrm{yr}$ (=OIS 11) and older than OIS 7 . As a consequence, the site belongs to either stage 11 or stage 9. Imprints of leaves and fruits of A. campestre and C. mas at the base of the Brockentuff indicate that the tephra erupted during an interglaciation. Because the eruption seems to have been followed immediately by deposition of sediments representing Kärlich Interglaciation II, as shown by the pollen sequence (Bittmann, 1992; p. 250), the Kärlich-Seeufer site likely dates to OIS 11. However, bearing in mind the possibility that Kärlich Interglaciation I and II deposits might represent two interglaciations, we cannot exclude a younger age (OIS 9) for the Seeufer site.

\section{PALEOBOTANY}

Palynological studies yielded important results for reconstructing the environmental and climatic conditions at the archaeological site (Bittmann, 1995). Paleobotanical studies were carried out on the limnic and telmatic (swampy) sedi- ments directly above the reworked Brockentuff (Fig. 3, unit a). Some of these interfinger with the debris-flow sediments containing the archaeological finds. Altogether, five pollen profiles were studied; two near the excavated area were intended to characterize the interglaciation, and three within the excavated area to characterize the environment during the deposition of the archaeological assemblage. Six major units with 14 local pollen zones $(\mathrm{lpz})$ were recognized in the pollen diagrams, spanning the Kärlich Interglaciation (II) and the onset of the following glaciation (Fig. 4).

\section{Quercetum mixtum Period (lpz I-3)}

This period is characterized by mixed oak forest and is considered the climatic optimum of the interglaciation. Thermophilous taxa like Celtis, C. mas, Hedera, and Syringa reach their maximum values in the pollen diagrams. In addition, the water fern Azolla filiculoides was found in this zone only. The vegetation of the lake indicates a transition from mesotrophic (lpz 1-2a) to eutrophic conditions ( $1 p z 2 b-3$ ).

\section{Carpinus and Quercetum mixtum Period (lpz 4-7)}

At the beginning of this period hornbeam became the dominant tree. The presence of fen vegetation indicates meso-eutrophic conditions in the lake from the end of $1 \mathrm{pz} 4$ onward. During this period the climate began to cool slightly at the beginning of $\mathrm{lpz} 6$ and more pronouncedly at the transition to $1 \mathrm{pz} 7 \mathrm{a}$ and $7 \mathrm{~b}$, the equivalent of the archaeological horizon (Fig. 3, unit d). Boreal forests and fen vegetation expanded. Meso-oligotrophic conditions prevailed in the lake (lpz 7).

\section{Pinus Period (lpz 8)}

During this period telmatic (swampy) conditions predominated in the area of the lake. A peat layer with many Menyanthes seeds records the almost complete infilling of the lake. Pinus invaded in these areas and is therefore overrepresented in the pollen diagram.

\section{Mülheim I Stade (lpz 9-10)}

Tundra vegetation dominated the landscape during this period, when further cooling of the climate is indicated. At the end, a lake again developed (limnic conditions in lpz 10).

\section{Kettig Interstade (Ipz II)}

Climatic amelioration during this period can be inferred and resulted in a small expansion of Quercus and Corylus. The second infilling of the lake, at the end, can be regarded as the result of a higher organic production rate in a temperate climate.

\section{Mülheim II Stade (lpz 12-14)}

Tundra vegetation again developed. In the course of this period, the climatic conditions improved once more (lpz 13) 


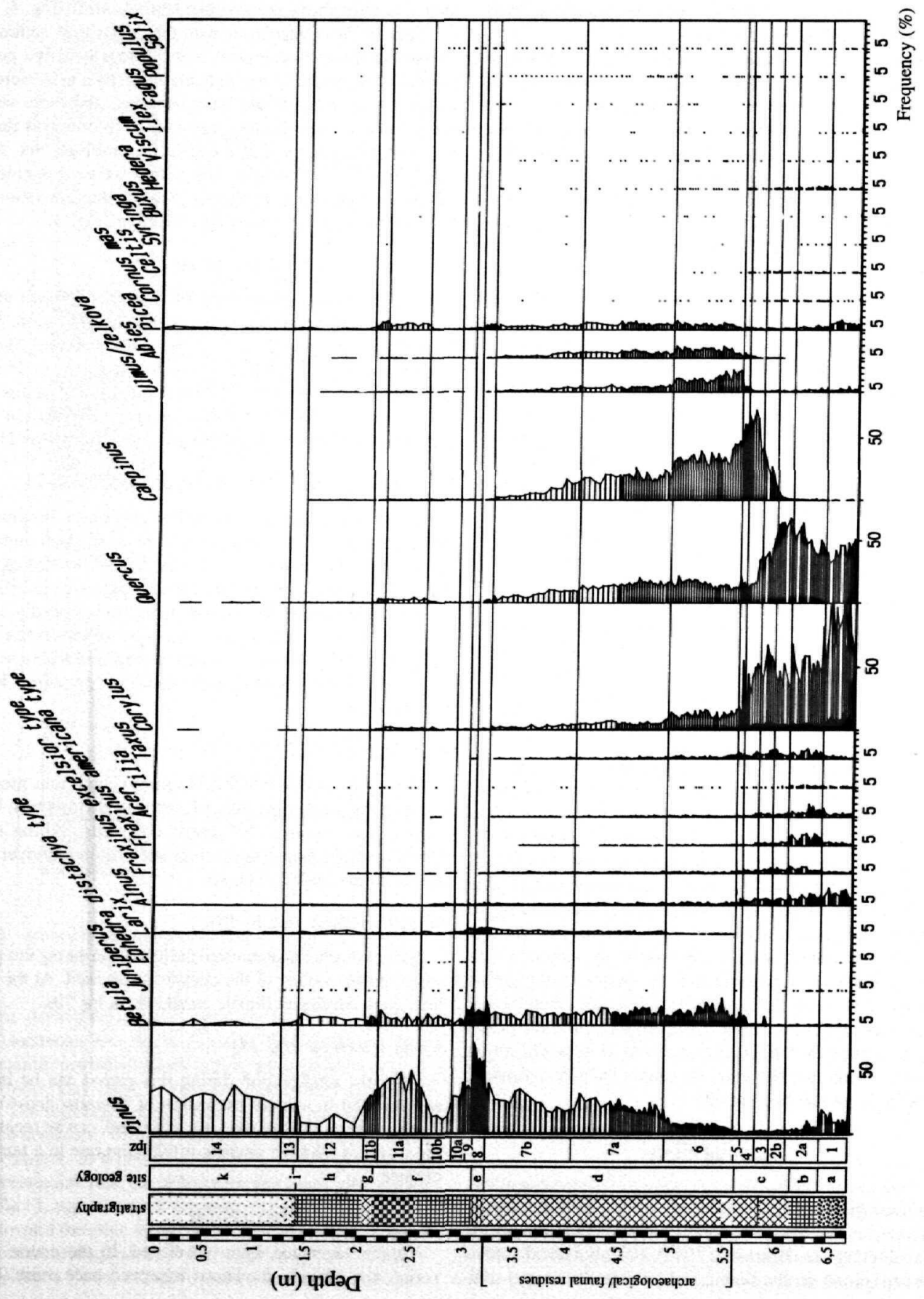




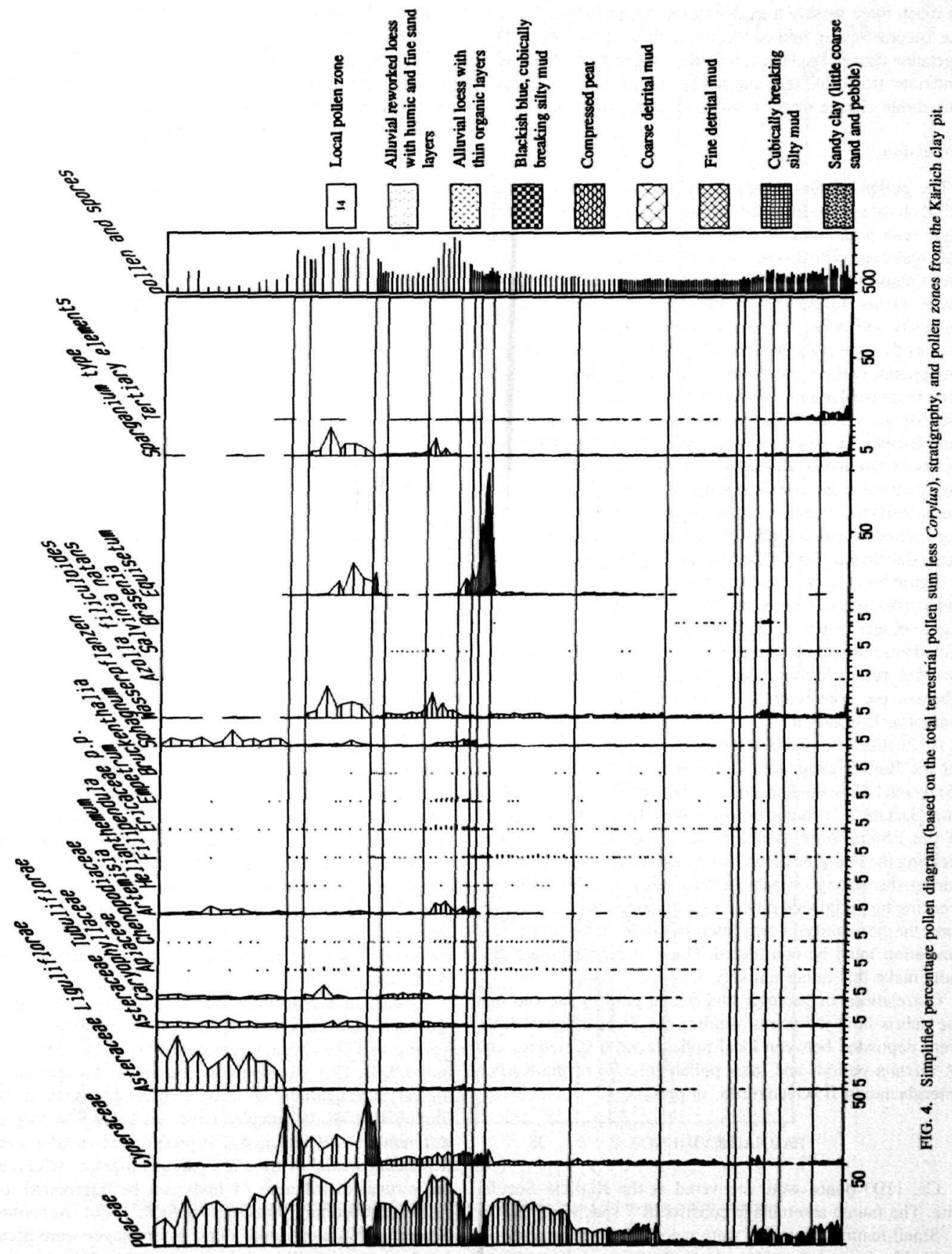


but much more weakly than during the Kettig Interstade. The lake become totally infilled. At the limit of lpz 13 to 14 the vegetation changed suddenly, indicating a transition of climatic conditions from cold and wet tundra to cold and dry steppe. This abrupt change marks a hiatus of unknown duration.

\section{Discussion}

The pollen profiles representing the Kärlich Interglaciation II show a range from the optimum phase of an interglaciation, with high amount of thermophilous elements, to glacial conditions. The distinct division of the Kärlich sequence into a phase with a well-developed and predominant Quercetum mixtum followed by a phase with the dominance of Carpinus and Abies is typical for the warm stages of the Cromer Complex (Zagwijn, 1992). Most likely, the sequence corresponds to the second optimum of the Cromer Interglaciation from Bilshausen (Niedersachsen, Germany) (Bittmann and Müller, 1996). The so-called Rhume Interglaciation from Bilshausen lasted more than $25,000 \mathrm{yr}$, as indicated by counts of laminated lake sediments. It was interrupted by a strong climatic deterioration $(<1000 \mathrm{yr})$ which transformed the interglacial vegetation into pine-birch forests. Afterward, climatic conditions improved and a mixed oak forest again developed. Fir needed nearly 2000 yr to immigrate.

Figure 5 compares the corresponding parts of the Kärlich and Bilshausen diagrams. Differences between the two are due to biogeographical reasons. Species with an Atlantic to Subatlantic distribution like Hedera, Ilex (not figured), and Corylus reach higher values in the Kärlich sequence, whereas the continentally distributed Picea is more important at Bilshausen.

A situation comparable to Bilshausen could be postulated for the Kärlich sequence. The interglacial molluscan fauna recovered below the Brockentuff (here referred to as Kärlich Interglaciation I) might be equivalent to the first optimum of the Rhume Interglaciation. As a consequence, the soil yielding the interglacial molluses should have been reworked during the strong climatic deterioration. Possible soil reworking by periglacial processes cannot be excluded. Therefore, the possibility of two interglaciations interrupted by a glaciation must be considered. However, the botanical results make this rather unlikely.

Correlations of geologic and pollen profiles showed that the debris-flow sediments yielding the archaeological finds were deposited between local pollen zone 6 (Carpinus and Q. mixtum period) and local pollen zone $7 \mathrm{~b}$ of the Kärlich Interglaciation II (Gaudzinski, in press).

\section{FAUNAL EVIDENCE}

Ca. 1100 bones were recovered at the Kärlich-Seeufer site. The faunal assemblage consists of 7 species (Table 1).

Small mammal remains were recorded from the archaeological horizon. A few Microtus molars were collected from loess-like deposits in the upper part of the sequence anc correlated with Kärlich J (Fig. 2).

The large mammal assemblage consists mainly of species preferring forested conditions and commonly regarded as indicators of an interglacial context (e.g., Elephas (Palaeoloxadon) antiquus, Sus scrofa). These species occur together with species preferring an open environment (e.g., Rangifer sp.). The combination of Rangifer sp. and E. (Palaeoloxodon) antiquus is unusual. The presence of large mammals preferring open conditions, such as Rangifer, corresponds to the presence of floral elements, indicating cold climatic conditions, such as Larix, found in the same stratigraphic position within the Seeufer site. In degree of preservation, the antler base of Rangifer found at Kärlich does not differ from bones of other species. Recent investigations of German postglacial sites have shown that Rangifer appeared during the Boreal interval in the context of a forested environment, together with a fauna preferring forested conditions (Steppan, 1993). Although these aspects suggest that the Kärlich-Seeufer faunal assemblage is probably autochthonous or parautochthonous, it cannot be excluded that the antler base of Rangifer represents a reworked faunal element, originally not belonging to the faunal assemblage.

\section{ARCHAEOLOGY}

The Seeufer site was excavated from 1980 to 1982 and again from 1987 until 1992 by Bosinski (Bosinski et al., 1980), Happe, Kulemeyer (1988), and especially by Kröger (Kröger et al., 1991). Altogether $417 \mathrm{~m}^{2}$ was excavated. The archaeological assemblage was subsequently studied in detail, together with the fauna, by Sabine Gaudzinski.

At the Kärlich-Seeufer site the sediments yielding the finds were deposited in a depression as debris flows during the Kärlich Interglaciation II. The excavated assemblage is dominated by more than 12,000 paleobotanical remains. Wood, hazelnuts, and other fruits are present (Fig. 6). Determinations of wood species were undertaken by Bittmann (Bittmann, 1995; Gaudzinski, in press), and 19 taxa were identified. Quercus and Abies dominate the tree spectrum and are preserved as trunks and branches. Nearly $90 \%$ of the wood is $<1 \mathrm{~m}$ long but one $6.5-\mathrm{m}$ trunk was recovered (Table 2).

Vertical and horizontal sorting of the wood pieces by species and size can be observed within the sediments, suggesting that the remains represent only a small number of individuals. This assumption is confirmed by dendrochronological investigations done by Leuschner. Relative dating implies that all 19 samples collected belong to only three different trees (Gaudzinski, in press). Size- and/or weightdependent spatial distribution patterns together with a regular vertical distribution of finds can be interpreted as the result of rebedding processes (Schick, 1986). According to Spicer (1989) most fossil floral assemblages were accumulated, or at least affected, by transport mechanisms. 


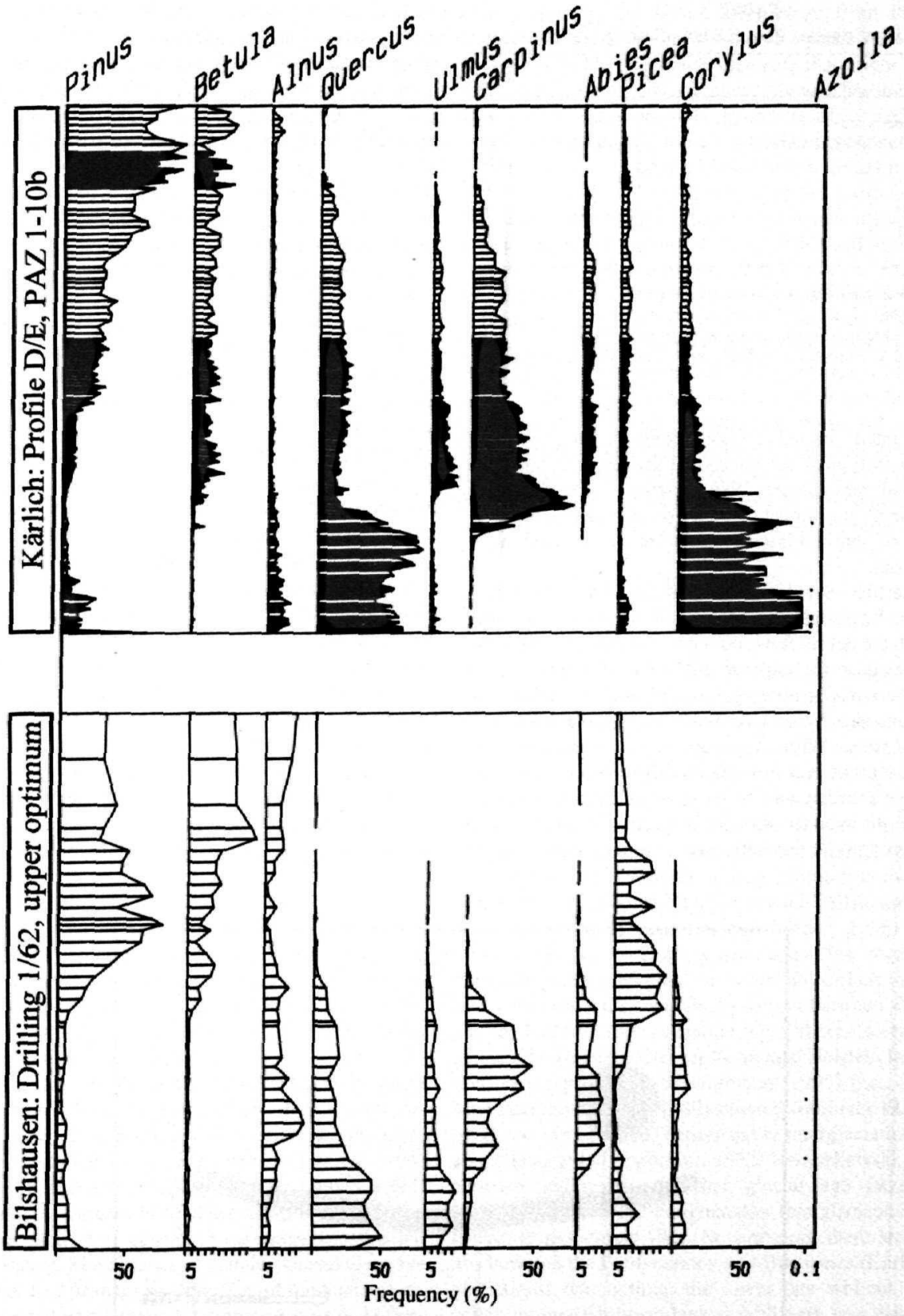

FIG. 5. Comparison of the corresponding parts from the Kärlich and Bilshausen pollen diagrams. 
TABLE 1

List of Species from Kärlich-Seeufer Site

\begin{tabular}{lcc}
\hline & MNI $^{a}$ & NISP $^{b}$ \\
\hline Panthera leo ssp. & 1 & 3 \\
Elephas (Palaeoloxodon) antiquus & 8 & $101^{c}$ \\
Equus sp. & 1 & 3 \\
Sus scrofa & 1 & 2 \\
Cervus elaphus & 1 & 18 \\
cf. Rangifer sp. & $1^{d}$ & 1 \\
Bos vel Bison & 4 & 26 \\
\hline
\end{tabular}

${ }^{a}$ MNI, minimum number of individuals per taxon.

${ }^{b}$ NISP, number of individual specimen per taxon.

'One hundred thirteen small ivory fragments not included.

${ }^{d}$ Rangifer sp. is represented by the basal part of a shed antler only.

Two "pointed" branches were recovered, but as pointing of branches is typical for abrasional processes in the case of transported trees (Spicer, 1989), hominid association with these fragments can almost certainly be excluded. Unambiguous traces of hominid interference were not detected in the wood material.

At the Kärlich-Seeufer site the sorting of wood can best be explained by postulating that most of the wood was redeposited with the debris-flow sediments. Sediments and wood were deposited on the edge of and within a swamp. These processes were responsible not only for the accumulation of the wood but also for at least part of the accumulation of artifacts and bones. Within the sediments a coherent archaeological find horizon was not observed. The vertical distribution of stone artifacts can be as great at $150 \mathrm{~cm}$ within 1 $\mathrm{m}^{2}$, and for the wooden remains $130 \mathrm{~cm}$. The bones were scattered through the deposits over a vertical distance of as much as $211 \mathrm{~cm}$ within $1 \mathrm{~m}^{2}$. Moreover, the presence of rolled artifacts and the taphonomy of the bones point to the mixed character of the artifact and bone assemblage.

The lithic assemblage consists of ca. 60 unmodified flakes; more than 50 retouched artifacts, most of them simple scrapers; 11 single-platformed unifacial or simple-platformed bifacial cores; 3 bifaces; and 4 cleavers (Figs. 7 and 8). Most of the artifacts are not easy to assess typologically. Only the bifaces place the whole assemblage in an Acheulean context. Simple modified flakes, as well as tools, are characterized by a high proportion of cortex; dorsal flake patterns resulting from previous knapping are rare. The number of dorsal scars rarely exceeds three and most striking platforms are cortical. Cleavers and bifaces were generally modified only to a minor extent since the form of the raw material used for manufacturing was chosen to be of similar shape to the desired finished tool.

With one exception only raw material from the local gravels or the Brockentuff was used for stone tool production: Devonian quartzite and quartz are dominant. A scraper made of Tertiary quartzite testifies to the exploitation of raw-material resources ca. $4 \mathrm{~km}$ distant from the site (Figs. 8.9).

That stone tool production occurred at or near the site is shown by refitting studies and the presence of cores and cortical flakes (Fig. 8). Although most of the artifacts are fresh and have sharp edges, the presence of some rolled artifacts indicates that the Seeufer assemblage might be a mixture of lithics from different time periods and locations (Gaudzinski, in press).

No causal relationship can be demonstrated between the presence of the stone artifacts and the faunal remains. The bones are almost complete. Long bone fragments larger than $10 \mathrm{~cm}$ and characterized by spiral fracture are extremely

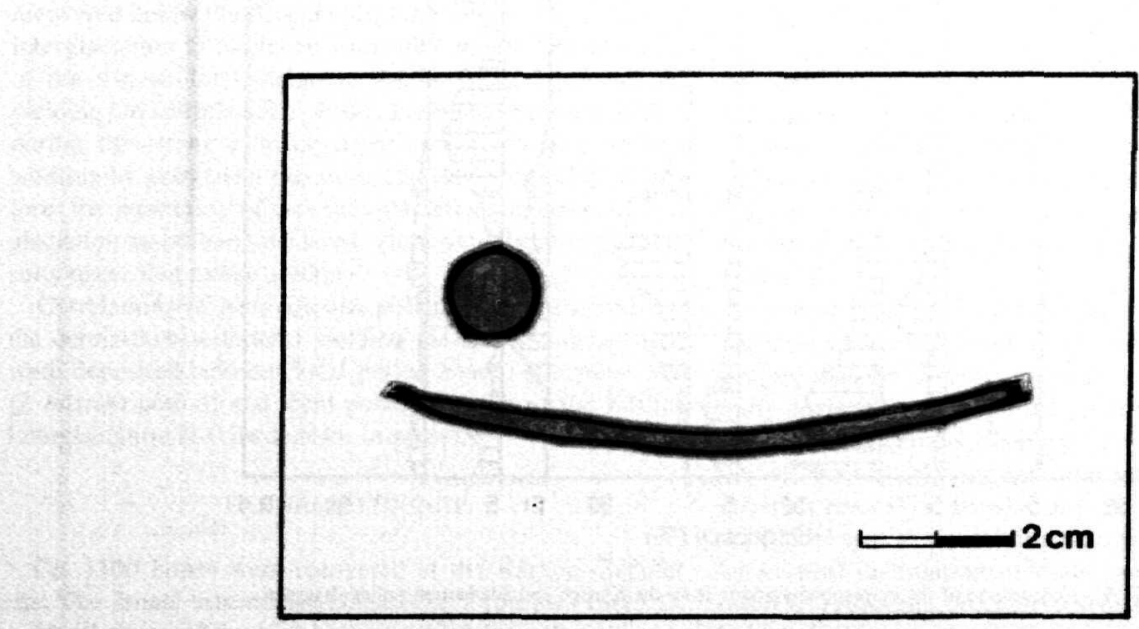

FIG. 6. Hazelnut and twig from the archaeological horizon of the Kärlich-Seeufer site. 
TABLE 2

Wooden Remains from the Kärlich-Seeufer Site $(n=7331$; Only Pieces with Excavation Coordinates without Characoals Included)

\begin{tabular}{|c|c|c|}
\hline & $\%$ & $n$ \\
\hline \multicolumn{3}{|l|}{ Taxaceae } \\
\hline Taxus (yew) & 0.5 & 37 \\
\hline \multicolumn{3}{|l|}{ Pinaceae } \\
\hline Abies (fir) & 58.7 & 4300 \\
\hline Picea/Larix (spruce/larch) & 1.0 & 76 \\
\hline Pinus (pine) & 0.04 & 3 \\
\hline \multicolumn{3}{|l|}{ Salicaceae } \\
\hline Salicaceae, total & 3.1 & 229 \\
\hline Popuius (popular) & 2.1 & 154 \\
\hline Salix (willow) & 0.7 & 49 \\
\hline \multicolumn{3}{|l|}{ Betulaceae } \\
\hline Betula (birch) & 4.2 & 299 \\
\hline Carpinus (hornbeam) & 1.4 & 100 \\
\hline Corylus (hazel) & 0.04 & 3 \\
\hline \multicolumn{3}{|l|}{ Fagaceae } \\
\hline Quercus (oak) & 11.5 & 844 \\
\hline \multicolumn{3}{|l|}{ Ulmaceae } \\
\hline Ulmus (elm) & 0.2 & 17 \\
\hline Celtis/Zelkova (nettle-trees/zelkova) & 0.08 & 6 \\
\hline \multicolumn{3}{|l|}{ Rosaceae } \\
\hline Pomoideae-type (pomaceous fruit) & 1.5 & 112 \\
\hline Prunoideae-type (stone-fruit) & 0.05 & 4 \\
\hline \multicolumn{3}{|l|}{ Aceraceae } \\
\hline Acer (maple) & 0.2 & 17 \\
\hline \multicolumn{3}{|l|}{ Cornaceae } \\
\hline Cornus (dogwoods) & 0.2 & 13 \\
\hline \multicolumn{3}{|l|}{ Oleaceae } \\
\hline Fraxinus (ashes) & 0.8 & 62 \\
\hline \multicolumn{3}{|l|}{ Caprifoliaceae } \\
\hline Lonicera (honeysuckle) & 0.02 & 2 \\
\hline \multicolumn{3}{|l|}{ Sambucaceae } \\
\hline Sambucus (elder) & 0.05 & 4 \\
\hline Indeterminate & 13.6 & 1000 \\
\hline
\end{tabular}

rare. Direct traces of human interference in the form of cut and fracture marks on the bones are lacking, but carnivore modification can be observed on the bones $(n=11)$. Analysis of mortality structures or skeletal element representation is difficult due to the small sample.

Scarcity of postcranial elements in the faunal assemblage likely is not the result of diagenetic events. For E. (Palaeoloxodon) antiquus, C. elaphus, and Bos vel Bison, the pressnce of teeth (high-density skeletal element; Lyman, 1994) and vertebrae (low-density skeletal element; Lyman, 1994) s documented. Assuming bone destruction by diagenetic rocesses after burial, low-density elements can be expected $o$ be rare or absent. The absence of certain skeletal elements nust be related to a primary modification of the thanatocoe1ose prior to burial or other site formation processes. Differint degrees of abiotic taphonomic processes (e.g., abrasion ind weathering) on the bone surfaces of all species testify o different necrologies (Fig. 9).
In summary, the faunal assemblage from the Kärlich Seeufer site gives the impression of a palimpsest deposit. It was not possible to identify elements that might have been the result of human interference. Though hominid interference cannot be convincingly demonstrated for the faunal and wood assemblage, the most reasonable interpretation is that the site represents remains of hominid activities in the vicinity. The quality and composition of the artifacts indicates that most of the tools represent a homogeneous assemblage. This is suggested by similar proportioned and flaked bifacial tools and the uniform preservation of most of the tool surfaces. Although only one refit comprising three simple flakes is present, a range of artifacts was produced from exactly the same raw material type. Moreover, most of the stone tools seem to be more-or-less contemporary with the sediment in which they were buried, for most are characterized by extremely sharp edges. Although the faunal assemblage seems to reflect a palimpsest deposit, mammal species representation is typical of an interglacial context. Preservation of wood requires rapid burial, and so the contemporaneity of floral remains and enclosing sediments seems plausible.

\section{DISCUSSION}

\section{Stratigraphy}

Apart from its archaeological record, the Kärlich-Seeufer site provides a basis for further discussion of the chronostratigraphic position of Middle Pleistocene interglaciations. The Kärlich Interglaciation is characterized by a distinct division into a phase with a well-developed and predominant $Q$. mixtum phase followed by a phase dominated by Carpinus and Abies, typical of warm stages of the Cromer Complex.

Among the known Cromer sites, the Kärlich sequence is in good agreement with the second optimum of the bipartite sequence of the Rhume Interglaciation of Bilshausen (Lower Saxony, Germany; Bittmann and Müller, 1996) which is overlain by clay of Elster glacial age. This, together with the geological context and dates for the Kärlich Interglaciation II, makes a chronological position between Cromer IV and the Holstein Interglaciation most likely. Interglacial sequences between the Cromer IV and the Holstein Interglaciation were reported by Klostermann (1995) [i.e., Römerhof Interglaciation (Urban, 1980) situated within the Elster Complex] and from Poland [Ferdynandov Interglaciation situated above (Janczykk-Kopikowa, 1975; Krzyszkowski, 1995) or between sediments of Elster glacial age (Rzechowski, 1996)]. However, the Ferdynandov Interglaciation was unknown from German sites. Nevertheless, there are similarities between the Ferdynandov and Bilshausen/Kärlich interglaciations: two optima, the lower one without Carpinus pollen grains (Ferdynandov) or with very low values (Bilshausen), the upper optimum with a large amount of Carpinus. The main difference between the Rhume Interglaciation of Bilshausen and the Ferdynandov Interglaciation is the 

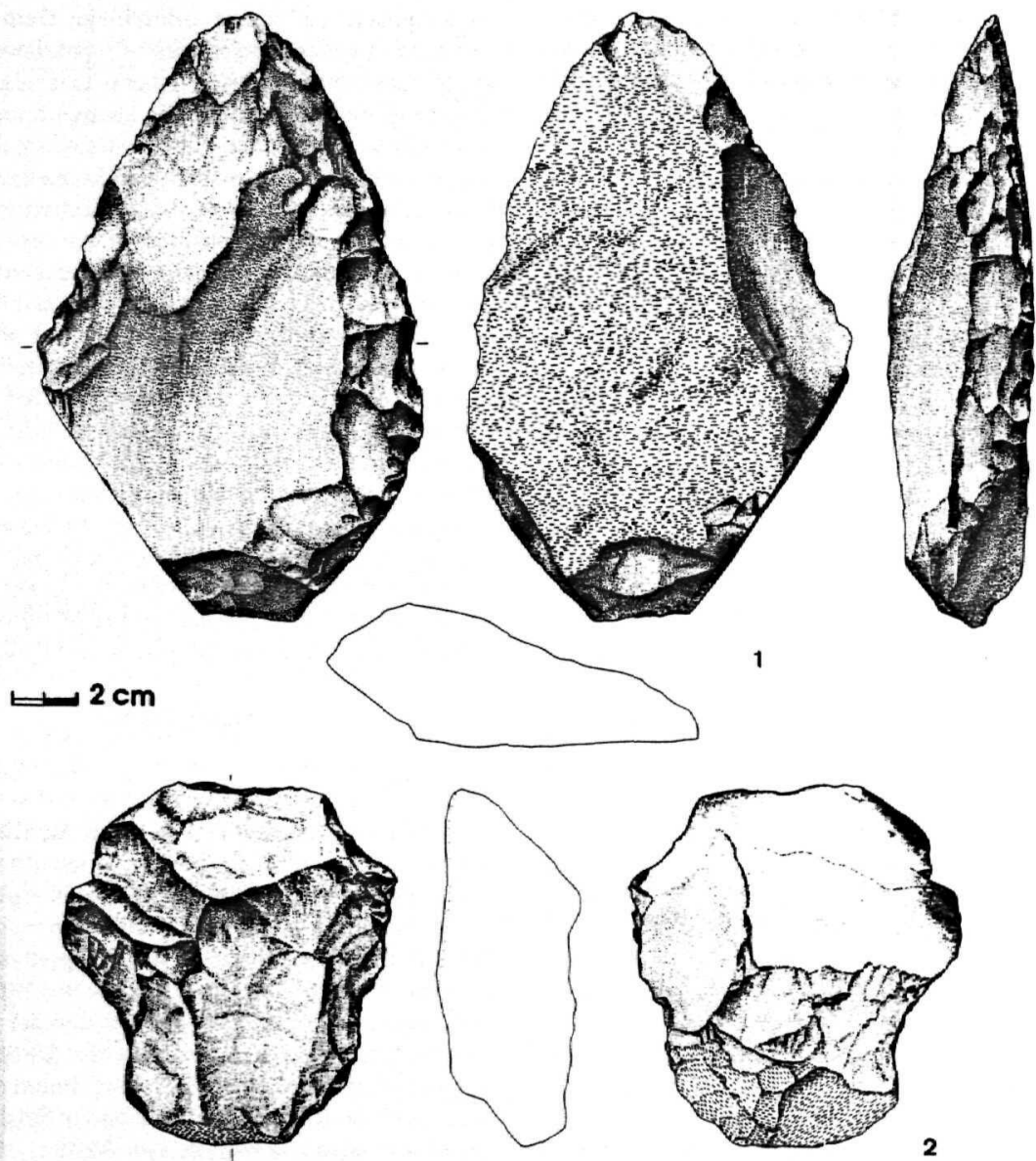

FIG. 7. Biface (1) and cleaver (2) made of Devonian quartzite from the Kärlich-Seeufer site.

stratigraphic position, interpreted as being below (Bilshausen) and above (Ferdynandov) Elster sediments.

An Eemian Interglacial age or an age younger than the Holstein Interglaciation, as suggested by Urban (1983), can be excluded for the Kärlich Interglaciation because of palynological characteristics of the pollen sequences studied by Bittmann (1995). A correlation with the Holstein Interglaciation sensu stricto is also not possible due to the low percentages of conifers, the unimportant role of Alnus, and the large amount of $Q$. mixtum and Carpinus. The same is true for the Wacken Interglaciation (Menke, 1968) and Dömnitz Interglaciation (Erd, 1973) which are very similar to the Holstein Interglaciation but differ from it in the lack of fir and in having lower values of thermophilous species.

The chronological position of the Holstein Interglaciation has been the subject of intense discussion. Correlation with marine isotope stage 7 was advocated by several authors using different methods, e.g., Miller and Mangerud (1986), Sejrup and Knudsen (1993, amino acids), Bombien (1987), Linke et al. (1986, ESR). and Schwarcz and Grün (1988, ESR, U-series). Other workers correlate the Holstein Interglaciation with isotope stage 9 (Zaqwijn, 1992, based on geology and palynology), stage 11 (Sar theim et al., 1986, based on ESR and U-series ages; de Beaulie 1 and Reille, 1995, based on palynology), or with stage 13 (Mani 1993, based on geomorphology). Assuming that the Kärlic ? Interglaciation I and II represent a single interglaciation, th geologic position and geophysical data show that the Kärlic Interglaciation most likely belongs to stage 11 . As a const quence, correlation of the Holstein Interglaciation with stage 1 can be excluded. 

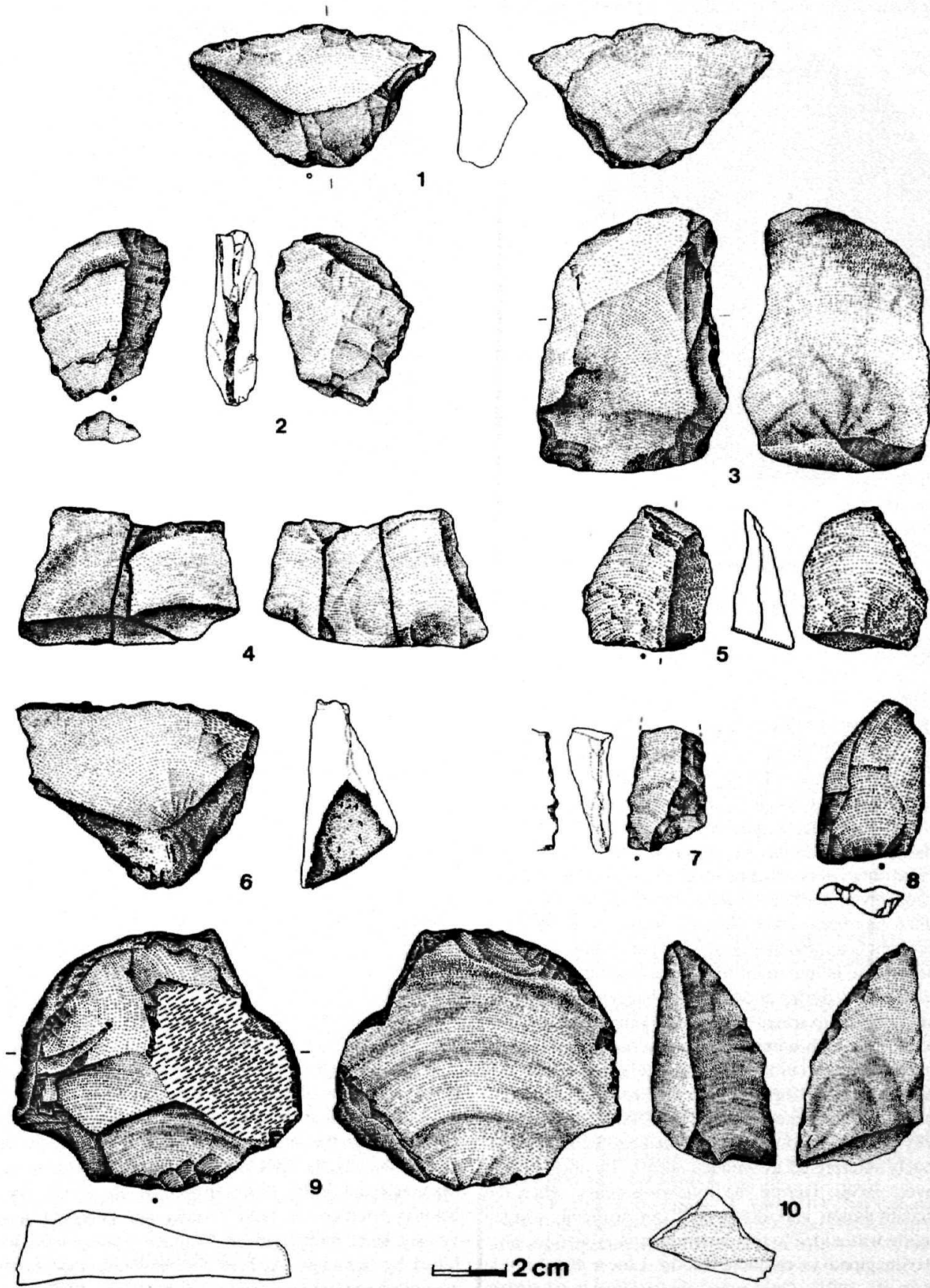

FIG. 8. Scrapers and simple flakes from the Kärich-Seeufer site. 1,3-7, and 10, Devonian quartzite; 2, 8, and 9, Tertiary quartzite. 


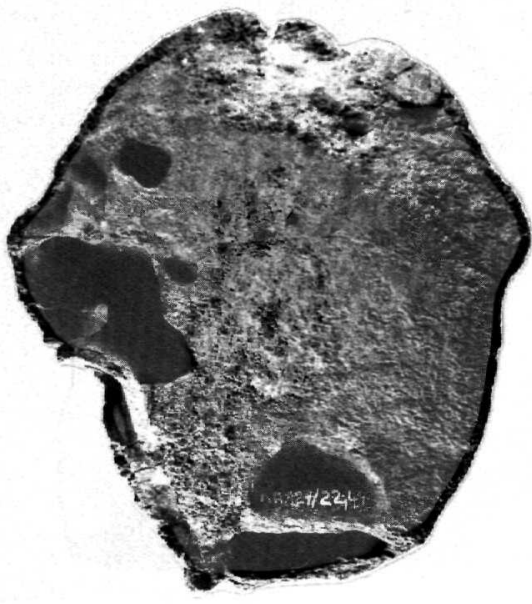

$2 \mathrm{~cm}$

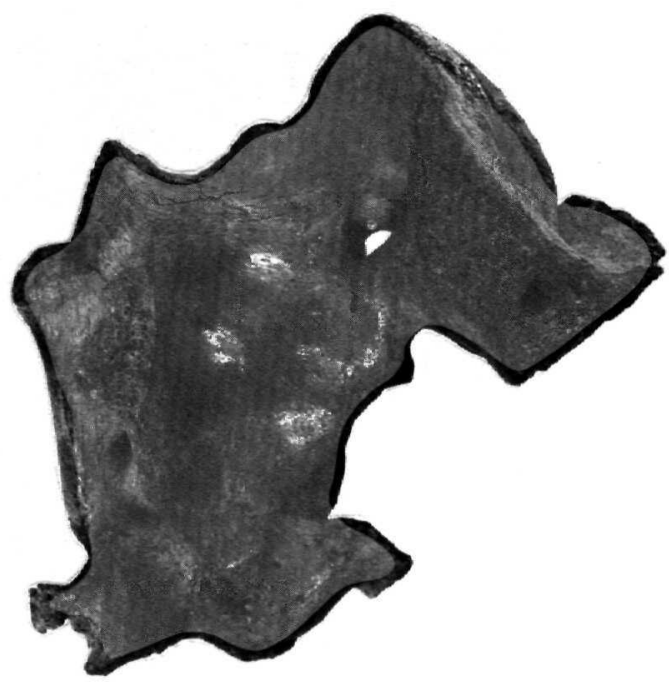

$2 \mathrm{~cm}$

FIG. 9. Skull fragments from the Kärlich-Seeufer site. (Right) Fragment of a basioccipitale with left condylus occipitale from Bos vel Bison preserved in a very fresh condition. (Left) Heavily abraded skull fragment.

\section{Archaeology}

The sediments and finds recovered at the Kärlich-Seeufer site were deposited on the edge of and within a former swamp exposed at the Kärlich clay pit (Rhineland, Germany). Although the Kärlich Seeufer site yielded a reworked archaeological sample, it proves that Middle Pleistocene hominids inhabited forested environments and shows that a much wider range of environments was exploited by palaeolithic occupants of northern Europe during the Middle Pleistocene than has been acknowledged on the basis of some recent ecological approaches (e.g., Gamble, 1986). The Kärlich-Seeufer site is important for the reconstruction of ecological conditions during a Middle Pleistocene interglacial phase and is a good example of the complexity of our geological records, in which hominids are only one variable.

Assuming the association of all finds, the site was interpreted as an elephant hunting camp as early as 1982 when only $50 \mathrm{~m}^{2}$ had been excavated. During the 1982 campaign, the first, badly preserved wood fragments came to light and were immediately interpreted as wooden spears (Bosinski, 1982; Kulemeyer, 1988). During the following years, when the wood accumulation was discovered, an artificial wooden construction was added to this interpretation as well as other elements imagined to characterize the Lower Palaeolithic (Kröger et al., 1991). Only when the site was analyzed in detail, taking into account the several geological processes that affected it, did it become obvious that a more conservative interpretation of the site is called for.

Together with Schöningen (Germany) (Thieme and Maier, 1995) and Benot Ya'aqov (Israel) (Goren-Inbar et al., 1992), the Kärlich-Seeufer site is one of the rare Lower Palaeolithic sites where wood remains have been preserved. Wooden spears and other wooden tools recently discovered at Schöningen show that the Lower Palaeolithic contains more than lithic tools. This is also underlined by the archaeological record from Castel di Guido (Italy) (Boschian, 1993), Fontana Ranuccio (Italy) (Segre et al., 1987), and Bilzingsleben (Germany) (Mania and Weber, 1986) where numerous bone tools have been discovered. Although at the Seeufer site the preservation of ca. 12,000 wood items is unique and outstanding, evidence for hominid interaction with this wood is missing.

The Kärlich-Seeufer site forms part of an assemblage, together with other Middle Pleistocene open-air sites, where faunal assemblages are dominated by $E$. (Palaeoloxodon) antiquus, although the data are still inadequate for specific interpretations. Among the sites are Torralba and Ambrona in Spain (Santonja and Villa, 1990; Howell et al., 1995). As at the Kärlich-Seeufer site, both Torralba and Ambrona have previously been interpreted as localities where elephants were killed by hominids. At least for Ambrona, taphonomic and zooarchaeological investigations (e.g., Klein, 1987), as well as quality and composition of the artifact assemblage, indicate 
that the record was severely affected by fluvial reworking. Although hominid interaction with the elephant assemblage is indicated by a few cut-marked bones (Shipman and Rose, 1983), hominid activity at the site is considered to have been minimal and discontinuous (Santonja and Villa, 1990). As Villa (1990) pointed out, exploitation of elephant remains by hominids also is ambiguous at Torralba.

Unambiguous functional interpretations of stone tool/ fauna associations are equally impossible for a few sites in Italy, where faunal assemblages are dominated by Elephas (Palaeoloxodon) antiquus (e.g., Rebibbia, La Polledrara, and Fontana Ranuccio). The topographic and geologic situations of the sites are connected with a fluvial or a limnic setting. The Rebibbia assemblage is interpreted as fluvially reworked material, coming from various sources and accumulated by hydrologic processes (Anzidei and Ruffo, 1985). At Fontana Ranuccio, the archaeological material was located directly below a soliffucted horizon (Biddittu et al., 1979). Because the bones are highly fragmented and bone surfaces show scratches, it remains unclear to what degree the archaeological layer was affected by the processes that disturbed the overlying sediments. La Polledrara (Italy) reflects in situ deposition of artifacts and bones within a marshy environment connected with a river bed. The taphonomic studies are not yet finished. Although hunting activities are not ruled out at La Polledrara, at least some of the animals may have died a natural death, and hominids possibly took advantage of this situation (Anzidei and Arnoldus-Huyzendveld, 1992).

In contrast to the ambiguous evidence from the sites mentioned above, several Middle and Upper Pleistocene in situ records indicate a clear hominid interference with elephant carcasses [(e.g., Notachirico, Italy (Cassoli et al., 1993); Aridos 1 and 2, Spain (Santonja and Villa, 1990); Gröbern, Germany (Erfurt and Mania, 1990); Lehringen, Germany (Thieme and Veil, 1985)]. The presence of large elephant bones from a single old individual, cut-marks on the bone surfaces, a close association of elephant remains and stone tools on the same paleosurface, and the homogeneity of the lithic assemblage indicated by a homogeneous fresh state of preservation and several lithic conjoins are elements which characterize most of these sites. Collectively, they suggest that Middle and Upper Pleistocene hominids interacted with elephant carcasses in a quite organized manner. The fact that records from such sites as La Polledrara differ remarkably from the single carcass sites might be an expression of a different mode of meat acquisition, but could also reflect different burial and/or site histories.

\section{ACKNOWLEDGMENTS}

The first author thanks F. Clark Howell, W. Roebroeks, and M. Street for useful criticism of the manuscript.

\section{REFERENCES}

Anzidei, A. P., and Ruffo, M. (1985). The Pleistocene deposit of Rebibbia-Casal de'Pazzi (Rome-Italy). In "Papers in Italian Archaeology:
The Human Landscape" (C. Malone and S. Stoddart, Eds.), Vol. IV, pp. 69-85. BAR International Series 243, Oxford.

Anzidei, A. P., and Arnoldus-Huyzendveld, A. (1992). The Lower Palaeolithic site of La Polledrara di Cecanibbio (Rome, Italy). In "New Developments in Italian Archaeology" (E. Herring, R. Whitehouse, and J. Wilkins, Eds.), pp. 141-153. Arcordia Research Centre, London.

Beaulieu, J.-L., de, and Reille, M. (1995). Pollen records from the Velay craters: A review and correlation of the Holsteinian Interglacial with isotopic stage 11. Mededelingen Rijks Geologische Dienst 52, 59-70.

Biddittu, I., Cassoli, P. F., Radicati di Brozolo, F., Segre, A. G., Segre Naldini, E., and Villa, I. (1979). Anagni, a K-Ar dated Lower and Middle Pleistocene site, Central Italy: Preliminary report. Quaternaria 21, 53 71.

Bittmann, F. (1992). The Kärlich Interglacial, Middle Rhine region, Germany: Vegetation history and stratigraphic position. Vegetation History Archaeobotany 1, 243-258.

Bittmann, F. (1995). Vegetationsgeschichtliche Untersuchungen an mittelund jungpleistozänen Ablagerungen des Neuwieder Beckens (Mittelrhein). Jahrbuch des Römisch-Germanischen Zentralmuseums Mainz 38, 83-190.

Bittmann, F., and Müller, H. (1996). The Kärlich Interglacial site and its correlation with the Bilshausen sequence. In "The Early Middle Pleistocene in Europe"' (C. Turner, Ed.), pp. 187-193. Balkema, Rotterdam.

Boenigk, W., Heye, D., Schirmer, W., and Brunnacker, K. (1974). Paläomagnetische Messungen an vielgliedrigen Quartär-Profilen (Kärlich/Mittelrhein und Bad Soden i. Taunus). Mainzer Naturwissenschaftiches Archiv 12, 159-168.

Boenigk, W., and Frechen, M. (in press a). Zur Geologie von KărlichSeeufer. Mainzer Geowissenschaftliche Mitteilungen.

Boenigk, W., and Frechen, M. (in press b). Zur Geologie von KärlichHauptwand. Jahrbuch des Römisch-Germanischen Zentralmuseums Mainz.

Bogaard, C., v.d., Bogaard, P., v.d., and Schmincke, H.-U. (1989). Quartärgeologisch-Tephrostratigraphische Neuaufnahme und Interpretation des Pleistozänprofils Kärlich. Eiszeitalter und Gegenwart 39, 62-86.

Bogaard, P., v.d., and Schmincke, H.-U. (1990). Die Entwicklungsgeschichte des Mittelrheinraumes und die Eruptionsgeschichte des Osteifel-Vulkanfeldes. In "Rheingeschichte zwischen Mosel und Maas" (W. Schirmer, Ed.), pp. 166-190. Deuqua-Führer 1, Hannover.

Bombien, H. (1987). "Geologisch-petrographische Untersuchungen zur quartären (früh-Saale-zeitlichen) Flußgeschichte im nördlichen Harzvorland." Mitteilungen des Geologischen Instituts der Universität Hannover 26, Hannover.

Boschian, G. (1993). Castel di Guido-Scavi 1980-1991. Atti della XXX Riunione Scientifica dell' Istituto Italiano di Preistoria e Protostoria, $167-178$

Bosinski, G., Brunnacker, K., Lanser, K. P., Stephan, S., Urban, B., and Würges, K. (1980). Altpalăolithische Funde von Kärlich, Kreis MayenKoblenz (Neuwieder Becken). Archäologisches Korrespondenzblatt 10, 295-314.

Bosinski, G. (1982). Die Ausgrabungen in Kärlich/Neuwieder Becken. Beil. Jahresber. Gerda-Henkel-Stiftung 1982, 9-20.

Brunnacker, K., Streit, R., and Schirmer, W. (1969). Der Aufbau des Quartär-Profils von Kärlich/Neuwieder Becken (Mittelthein). Mainzer Naturwissenschafliches Archiv 8, 102-133.

Cassoli, P. F., Lefevre, D., Piperno, M., Raynal, J. P., and Tagliacozzo, A. (1993). Una paleosuperficie con resti de Elephas (Palaeoloxodon) antiquus e industria acheuleana nel sito di Notachirico (Venosa, Basilicata). Atti della XXX Riunione scientifica dell' Istituto Italiano di Preistoria e Protostaria, 101-116.

Erd, K. (1973). Vegetationsentwicklung und Biostratigraphie der Dömnitz- 
Warmzeit (Fuhne/Saale 1) im Profil von Pritzwalk/Prignitz. Abhand. lungen des Zentralen Geologischen Instituts 18, 9-48.

Erfurt, J., and Mania, D. (1990). Zur Palăontologie des jungpleistozänen Waldelefanten von Gröbern, Kreis Gräfenhainichen. In "NeumarkGröbern. Beiträge zur Jagd des mittelpaläolithischen Menschen"' (D. Mania, M. Thomae, T. Litt, and T. Weber, Eds.), pp. 215-224. Deutscher Verlag der Wissenschaften, Berlin.

Frechen, M. (1995). Eruptionsgeschichte und Deckschichtfolge der Wannenköpfe-Vulkangruppe in der Osteifel. Eiszeitalter und Gegenwart 45, 107-127.

Gamble, C. S. (1986). “The Palaeolithic Settlement of Europe." Cambridge Univ. Press, Cambridge.

Gaudzinski, S. (in press). Kärlich-Seeufer. Untersuchungen zu einer altpaläolithischen Fundstelle im Neuwieder Becken (Rheinland/Deutschland) Jahrbuch des Römisch-Germanischen Zentralmuseums Mainz.

Goren-Inbar, N., Belitzky, S., Verosub, K., Werker, E., Kislev, M., Heimann, A., Carmi, L., and Rosenfeld, A. (1992). New discoveries at the Middle Pleistocene Acheulian site of Gesher Benot Ya'aqov, Israel. Quaternary Research 38, 117-128.

Janczyk-Kopikowa, Z. (1975). Flora interglacjalu mazowieckiego w Ferdynandowie. Biuletyn Instytutu Geologicznego 290, 5-96.

Howell, F. C., Butzer, K. W., Freeman, L. G., and Klein, R. G. (1995). Observations on the Acheulean occupation site of Ambrona (Soria Province, Spain). Jahrbuch des Römisch-Germanischen Zentralmuseums Mainz 38, 33-82.

Klein, R. G. (1987). Reconstructing how early people exploited animals: Problems and prospects. In "The Evolution of Human Hunting"' (M. H and D. V. Nitecki, Eds.), pp. 11-45. Plenum, New York.

Klostermann, J. (1995). Nordrhein-Westfalen. In "Das Quartär Deutschlands" (L. Benda, Ed.), pp. 59-94. Gebruder Borntraeger, Berlin, Stuttgart.

Kolfschoten, T. v. (1990). The evolution of the Marnmal Fauna in the Netherlands and the Middle Rhine Area (Western Germany) during the Late Middle Pleistocene. Mededelingen Rijks Geologische Dienst 43, 1 69.

Kolfschoten, T. v., and Turner, E. (1996). Early Middle Pleistocene mammalian faunas from Kärlich and Miesenheim I and their biostratigraphical implications. In "The Early Middle Pleistocene in Europe" (C. Turner, Ed.), pp. 227-253. Balkema, Rotterdam.

Kröger, K., Bogaard, P., v.d., Bittmann, F., and Turner, E. (1991). Der Fundplatz Kärlich-Seeufer. Neue Untersuchungen zum Altpaläolithikum im Rheinland. Jahrbuch des Römisch-Germanischen Zentralmuseums Mainz 35, 111-135.

Kryzyszkowski, D. (1995). An outline of the Pleistocene Stratigraphy of the Kleszczów Graben, Belchatów outcrop, Central Poland. Quaternary Science Review 14, 61-83.

Kulemeyer, J. (1988). "Die alt- und mittelpaläolithischen Funde von Kärlich." Ph.D. dissertation, Unversität zu Köln.

Linke, G., Katzenberger, O., and R. Grün (1986). Description and ESR dating of the Holstein Interglaciation. Quaternary Science Review 4, 319331.

Lippolt, H. J., Fuhrmann, U., and Hradetzky, H. (1986). ${ }^{40} \mathrm{Ar} /{ }^{39} \mathrm{Ar}$ age determinations on sanidines of the Eifel Volcanic Field (FRG): Constrains on age and duration of a Middle Pleistocene cold period. Chemical Geology 59, 187-204.

Lyman, R. L. (1994). "Vertebrate Taphonomy." Cambridge Univ. Press, Cambridge.

Mania, D. (1993). Die Terrassen-Travertin-Sequenz von Bilzingsleben. Ein Beitrag zur Stratigraphie des Mittel- und Jungpleistozäns im Elbe-SaaleGebiet. Ethnographisch-Archäologische Zeitschrift 34, 554-575.

Mania, D., and Weber, T. (Eds.), (1986). "Bilzingsleben III. Homo erectus-seine Kultur und seine Umwelt." Deutscher Verlag der Wissenschaften, Berlin.

Menke, B. (1968). Beiträge zur Biostratigraphie des Mittelpleistozäns in Norddeutschland. Meyniana 18, 35-42.

Miller, G. H., and Mangerud, J. (1986). Aminostratigraphy of European marine interglacial deposits. Quaternary Science Reviews 4, 215-278.

Razi Rad, M., (1976). "Schwermineraluntersuchungen zur Quartär-Stratigraphie am Mittelrhein." Sonderveröffentlichungen des Geologischen Institutes der Universität zu Köln 28, Köln.

Rzechowski, J. (1996). The Ferdynandowian Interglacial and its stratigraphical position in the Middle Pleistocene of Europe. In "The Early Middle Pleistocene in Europe”' (C. Turner, Ed.), pp. 279-293. Balkema, Rotterdam.

Santonja, M., and Villa, P. (1990). The Lower Palaeolithic of Spain and Portugal. Journal of World Prehistory 4, 45-93.

Sarntheim, M., Stremme, H. E., and Mangini, A. (1986). The Holstein Interglaciation: Time-stratigraphic position and correlation to stable isotope stratigraphy of deep sea sediment. Quaternary Research 26, 283298.

Schick, K. D. (1986). "Stone Age Sites in the Making." BAR International Series 319, Oxford.

Schirmer, W. (1990). Kärlich-Forschungsstand 1990. In "Rheingeschichte zwischen Mosel und Maas"' (W. Schirmer, Ed.), pp. 60-67. Deuqua-Führer 1, Hannover.

Schwarcz, H. P., and Grün, R. (1988). Comment on M. Sarntheim, H. E. Stremme, and A. Mangini, "The Holstein Interglaciation: Time-stratigraphic position and correlation to stable isotope stratigraphy of deepsea sediments." Quaternary Research 29, 75-79.

Segre, A. G., Biddittu, I., and Guadagnoli, F. (1987). Nuovi dati sul giacimento del Paleolitico Inferiore di Anagni-Fontana Ranuccio. Archeologia Laziale 8, 239-243.

Sejrup, H. P., and Knudsen, K. L. (1993). Paleoenvironment and correlations of interglacial sediments in the North Sea. Boreas 22, 223-235.

Shipman, P., and Rose, J. (1983). Evidence of butchery and hominid activities at Torralba and Ambrona: An evaluation using microscopic techniques. Journal of Archaeological Science 10, 465-474.

Spicer, R. A. (1989). The formation and interpretation of plant fossil assemblages. In "Advances in Botanical Research" (J. A. Callow, Ed.), pp. 95-191. Academic Press, London, San Diego.

Steppan, K. H. (1993). Osteologische und taphonomische Untersuchungen an Tierknochenfunden aus der mesolithischen Freilandfundstelle Rottenburg-Siebenlinden I, Lkr. Tübingen. Zeitschrift für Archäologie 27, 9-16.

Thieme, H., and Maier, R. (Eds.) (1995). "Archäologische Ausgrabungen im Braunkohlentagebau Schöningen, Landkreis Helmstedt." Verlag Hahnsche Buchhandlung, Hannover.

Thieme, H., and Veil, S. (1985). Neue Unterscuhungen zum eemzeitlichen Elefanten-Jagdplatz Lehringen, Ldkr. Verden. Die Kunde 36, 11-58.

Urban, B. (1978). Die Stellung des Kärlicher Brockentuffs im Kärlicher Interglazial am Mittelrhein. In "Beiträge zur Quartär- und Landschaftsforschung”' (H. Nagl, Ed.), pp. 649-654. Festschrift y. Fink, Wien.

Urban, B. (1980). Palăoökologische Untersuchungen zum Krefeld-Interglazial am Niederrhein. Eiszeitalter und Gegenwart 30, 73-88.

Urban, B. (1983). Biostratigraphic correlation of the Kärlich Interglacial, Northwestern Germany. Boreas 12, 83-90.

Villa, P. (1990). Torralba and Aridos: Elephant exploitation in Middle Pleistocene Spain. Joumal of Human Evolution 19, 299-309.

Zagwijn, W. H. (1985). An outline of the Quaternary stratigraphy of the Netherlands. Geologie en Mijnbouw 64, 17-24.

Zagwijn, W. H. (1992). The beginning of the Ice Age in Europe and its major subdivision. Quaternary Science Reviews 11, 583-592. 